\title{
ACT OF INFORMATION AND ELECTRONIC TRANSACTIONS IN SOCIOLOGY PERSPECTIVE
}

\section{UNDANG-UNDANG INFORMASI DAN TRANSAKSI ELEKTRONIK DALAM PERSPEKTIF SOSIOLOGI}

\author{
Agus Satory, S.H., M.H.* \\ gusto_adini@yahoo.com \\ (Diterima pada: 05-06-2017 dan dipublikasikan pada: 01-12-2017)
}

\begin{abstract}
ABSTRACK
The development of information and communication technology has also caused world relations to become borderless and cause significant social, economic and cultural change to take place so quickly. Such rapid advances in information technology have contributed greatly to the development of the world of information and electronic transactions. However, it can not be denied that such great progress on one side brings benefits to humanity, but on the other hand it can also bring harm to humanity. The provisions of Law Number 11 Year 2008 in conjunction with Law Number 19 Year 2016 on Information and Electronic Transactions in the perspective of sociology is due to the will to meet the legal needs of the community, including laws that reflect the cultural values of a nation (latency). Where many events show that people demand different ways of interception and threats of defamation that are considered too heavy so that sanctions to the treatment of offenders is considered more severe than the actions done.
\end{abstract}

Key Words: Information, Electronic Transactions, Sociology Perspective

\begin{abstract}
ABSTRAK
Perkembangan teknologi informasi dan juga komunikasi sudah menyebabkan hubungan dunia menjadi tanpa batas (borderless) dan juga menyebabkan perubahan sosial, ekonomi dan budaya secara signifikan berlangsung demikian cepat. Kemajuan yang begitu pesat dalam bidang teknologi informasi telah memberikan sumbangan yang besar bagi berkembangnya dunia informasi dan transaksi elektronik. Akan tetapi, tidak dapat dipungkiri, kemajuan yang begitu dahsyat tersebut di satu sisi membawa manfaat bagi kemanusiaan, tetapi di sisi yang lain juga dapat membawa mudharat bagi kemanusiaan. Ketentuan Undang-Undang Nomor 11 Tahun 2008 juncto Undang-Undang Nomor 19 Tahun 2016 tentang Informasi dan Transaksi Elektronik dalam perspektif sosiologi adalah karena adanya kehendak untuk memenuhi kebutuhan hukum masyarakat, termasuk di dalamnya hukum yang mencerminkan nilai-nilai kebudayaan dari suatu bangsa (latency). Dimana banyaknya peristiwa yang memperlihatkan bahwa masyarakat menuntut cara yang berbeda dalam pengaturan intersepsi dan ancaman pencemaran nama baik yang dianggap terlalu berat sehingga sanksi hingga perlakuan terhadap pelanggarnya dianggap lebih berat dari perbuatan yang dilakukan.
\end{abstract}

Kata Kunci : Sosiologi, Informasi, dan Transaksi Elektronik

* Dosen Pengantar Hukum Telematika FH Universitas Pakuan Bogor dan Mahasiswa Program Doktor Ilmu Hukum (S3) Program Pascasarjana Universitas Sebelas Maret Surakarta 


\section{A. Pendahuluan}

Perkembangan dan kemajuan teknologi informasi yang sedang melanda dunia sekarang dan cukup dirasakan juga di negara Indonesia yang sedemikian pesatnya, sudah menyebabkan perubahan kegiatan kehidupan manusia di dalam berbagai bidang yang sudah mempengaruhi munculnya bentuk-bentuk perbuatan hukum baru yang berhubungan dengan teknologi informasi. Perkembangan demikian tampak dalam apa yang dinamakan "Globalisasi Informasi" sudah menempatkan Indonesia sebagai suatu bagian dari masyarakat informasi dunia. ${ }^{1}$

Perkembangan teknologi informasi dan juga komunikasi menyebabkan hubungan dunia menjadi tanpa batas (borderless) serta menyebabkan perubahan sosial, ekonomi dan budaya secara signifikan berlangsung demikian cepat. Teknologi informasi mencakup masalah sistem yang mengumpulkan (collect), menyimpan (save), memproses, memproduksi dan mengirimkan informasi dari dan ke industri ataupun masyarakat secara efektif dan cepat. Demikian juga Indonesia, dimana penggunaan teknologi informasi yang berkembang dengan sangat cepat dan semakin penting artinya bagi masyarakat. Pemanfaatannya pun sudah semakin meluas sampai memasuki hampir semua segi kehidupan. ${ }^{2}$

Kemajuan yang sangat pesat pada bidang teknologi informasi sudah memberikan kontribusi yang sangat besar bagi perkembangan dunia informasi dan transaksi elektronik. Akan tetapi, tidak dapat

${ }^{1}$ Yahya Ahmad Zein, Kontrak Elektronik \& Penyelesaian Sengketa Bisnis E-Commerce : Dalam Transaksi Nasional \& Internasional, (Bandung : Mandar Maju, 2009), hlm. v.

${ }^{2}$ M. Arsyad Sanusi, Hukum dan Teknologi Informasi, Cet. 3, 2005, hlm. 3.. Baca juga Susilo Bambang Yudoyono "Sumbangan ICT dalam Membangun Good Govenrannce Amat Besar" dimuat dalam e-Indonesia, Vol. 1, Edisi Juni 2005, hlm. 25-27. dipungkiri, kemajuan yang dahsyat tersebut di satu sisi membawa manfaat bagi kemanusiaan, tetapi di sisi yang lain juga dapat membawa mudharat bagi kemanusiaan. Kemajuan dalam bidang informasi dan transaksi elektronik sudah menempatkan manusia pada posisi yang semakin paripurna dalam mengembangkan misi kekhalifahan di muka bumi tetapi juga bisa berpotensi menggelincirkan posisi kemanusiaan pada titik terendah ketika penggunaan informasi juga transaksi elektronik dimanfaatkan secara tidak bertanggung jawab dengan menyerang kehormatan dan nama baik orang lain. Apabila tumbuh marak berbagai bentuk kejahatan akan tetapi tidak ada hukuman yang mengatur dan juga bersifat memaksa, maka kejahatan-kejahatan tersebut akan membunuh masyarakat dimana kejahatan itu berada.

Keberadaan dunia maya ataupun dunia siber (cyberspace) merupakan sebuah konstruksi maya yang diciptakan oleh sebuah komputer yang di dalamnya berisikan data-data abstrak yang berfungsi sebagai berikut : (1) aktualisasi diri; (2) tempat bertukar gagasan; dan juga (3) sarana penguatan prinsip demokrasi. Manusia bisa masuk ke dalam sistem data dan jaringan komputer tersebut kemudian mendapatkan suatu perasaan bahwa mereka benar-benar telah memasuki suatu ruang yang tidak ada keterikatan sama sekali antara realitasrealitas fisik. Oleh sebab itu, aktivitasaktivitas di dunia siber mempunyai karakter, yaitu: (1) mudah, penyebarannya sangat cepat dan meluas yang bisa diakses oleh setiap orang dan dimanapun, dan (3) bisa bersifat destruktif dari pemuatan materi penghinaan dan/atau pencemaran nama baik dengan memakai media elektronik sangat luar biasa karena memiliki corak viktimisasi yang tidak terbatas. Dengan memahami hakikat dunia siber beserta karakternya, maka dibutuhkan pengaturan tersendiri untuk mengakomodasi 
perkembangan dan konvergensi teknologi informasi, yang bisa dipakai sebagai sarana dalam melakukan kejahatan.

Mengenai perbedaan prinsipil diantara dunia ciber dengan dunia nyata, kita berpendapat bahwa pembeda utama antara interaksi di dunia nyata (real/physical world) dan dunia siber (cyberspace) hanyalah dari sudut media yang digunakan, maka seluruh interaksi dan aktivitas melalui internet akan mempunyai dampak bagi kehidupan manusia dalam dunia nyata, misalnya melalui transfer data, melalui distribusi dan/atau transmisi atau dapat diaksesnya informasi dan dokumentasi elektronik juga bisa menimbulkan dampak negatif yang sangat ekstrim dan massif di dunia nyata. Landasan pemikiran inilah yang pada tahun 2008 mendasari lahirnya Undang-Undang No. 11 Tahun 2008 tentang Informasi dan Transaksi Elektronik (selanjutnya disebut UU ITE) yang kini telah diubah dengan Undang-Undang No. 19 Tahun 2016.

Melihat kondisi tersebut terdapat kontradiksi dimana hukum sejatinya bukan merupakan suatu tujuan, melainkan suatu sarana untuk mencapai tujuan, baik aspek keadilan, kepastian hukum dan juga kemanfaatan hukum. Sehingga bisa dipahami peraturan bukan sebagai pencapaian akhir dari pembentukan hukum. Aspek konstitusionalitas dan aspek sosial atau dorongan pertumbuhannya (groei stimulus) dari luar hukum termasuk variabel yang akan mempengaruhi efektivitas peraturan tersebut menjadi penting untuk dijadikan dasar dalam melakukan suatu langkah yang sudah tepat dalam menghasilkan undang-undang yang lebih baik. Dari latar belakang tersebut maka dianggap perlu untuk melakukan perubahan UU ITE dengan harapan bisa mendorong pencapaian dari tujuan dibentuknya UU ITE itu sendiri dan secara umum bisa mendorong pencapaian keadilan, kepastian dan kemanfaatan hukum.
Membahas perkembangan teknologi tidak bisa dipisahkan dari teknologi informasi. Kemajuan teknologi informasilah yang telah menyebabkan suatu ledakan kemajuan peradaban manusia, ledakan impian yang menjadi kenyataan. Bila mengkaji mengenai kemajuan teknologi informasi, maka hal tersebut tidak bisa dipisahkan dari suatu perkembangan teknologi komputer dan internet. Komputer dan juga internet sebagai suatu penemuan yang begitu mengagumkan merupakan awal dari pencapaian apa yang sudah manusia rasakan saat ini. Sebab, komputer dan internet sudah mengubah budaya manusia dari budaya industri menjadi budaya yang berlandaskan informasi. Budaya di mana informasi menjadi kebutuhan penting, bisa diakses tidak terbatas dan juga tanpa batas (borderless). Budaya di mana setiap orang berhak mendapatkan pengetahuan seluas-luasnya.

Selain mengubah budaya manusia, komputer dan juga internet sangat berperan besar terhadap apa yang sudah dicapai masyarakat di dunia pada saat ini. Hampir segala aspek kehidupan tidak dapat dilepaskan dari komputer dan internet. Dari sejak bangun tidur hingga tidur kembali, manusia bersentuhan dengan komputer dan internet atau minimal produk yang dihasilkan melalui bantuan komputer dan internet. $^{3}$

Sebagai contoh paling mudah, masyarakat terutama yang terletak di kotakota besar sangat sulit melepaskan diri dari teknologi listrik. Sudah jamak diketahui perusahaan listrik tidak akan terlepas dari penggunaan komputer dan internet untuk mengatur dan menjaga pasokan listrik ke pelanggan. Bagaimana dengan bank? Bank dekade ini sangat mengandalkan teknologi komputer dan internet. Karena dengan kedua teknologi tersebut bank pusat dapat berkoordinasi dengan bank-bank cabang secara online dan real time. Hal tersebut tentunya untuk memenuhi tuntutan

${ }^{3}$ Budi Agus Riswandi, Hukum dan Internet di Indonesia, (Yogyakarta : UII Press, 2003), hlm. 1. 
kebutuhan nasabah yang membutuhkan transaksi secara cepat. Dengan, memanfaatkan teknologi komputer dan internet, bank bisa melayani nasabah bukan hanya dalam ruang lingkup lokal dan regional tetapi juga mampu melayani secara global.

Kemajuan teknologi informasi
terutama pada bidang komputer dan internet terbukti telah memberikan dampak positif bagi kemajuan kehidupan manusia. Perlu digarisbawahi, dibalik kelebihan dan kemudahan yang ditawarkan oleh komputer dan internet, ternyata memiliki sisi negatif yang dapat menghancurkan kehidupan dan budaya manusia itu sendiri. Dimana menurut Prof. Dr. Insan Budi Maulana, S.H., LL.M., bahwa perkembangan informasi, komunikasi dan teknologi atau dikenal dengan istilah information and communication technology (ICT) berpengaruh terhadap perilaku sosial dan budaya masyarakat. ${ }^{4}$ Sedangkan menurut Prof. Dr. Jamal Wiwoho, S.H., M.Hum., bahwa teknologi informasi dan komunikasi telah mengubah perilaku dan pola hidup masyarakat secara global. Perkembangan teknologi informasi telah pula menyebabkan dunia menjadi tanpa batas (borderless) dan menyebabkan perubahan sosial, budaya, ekonomi dan pola penegakan hukum yang secara signifikan berlangsung demikian cepat. ${ }^{5}$

Salah satu cara untuk mengubah level penegakan hukum adalah melalui teknologi. Pada akhirnya seseorang bisa menemukan sebuah selang anti bocor. Masyarakat secara keseluruhan mungkin tidak ingin menginvestasikan lebih banyak

\footnotetext{
${ }^{4}$ Insan Budi Maulana, "Informasi Komunikasi dan Teknologi : Perkembangan dan Perubahan Hukum", Materi Kuliah Hukum dan Teknologi Informasi pada Program Doktor Ilmu Hukum Program Pascasarjana Fakultas Hukum Universitas Sebelas Maret Surakarta, 20 Mei 2016.

${ }^{5}$ Jamal Wiwoho, "Naskah Akademik Rancangan Undang-Undang tentang Informasi dan Transaksi Elektronik", tersedia di http://jamalwiwoho.com/wp-

content/uploads/2010/10/NA-RUU-ITE.pdf , diakses tanggal 15 Agustus 2016.
}

uang lagi di bidang penegakan hukum, tetapi suatu terobosan tertentu bisa jadi akan membuahkan hasil yang lebih baik, persis seperti halnya alat dan bibit yang lebih baik bisa menumbuhkan jagung yang lebih baik dari sebidang tanah pertanian yang sama. ${ }^{6}$

Berdasarkan uraian di atas, penulis tertarik untuk mengangkat permasalahan tersebut dan menuangkannya dengan judul "Undang-Undang Informasi Dan Transaksi Elektronik Dalam Perspektif Sosiologi"'.

Berdasarkan latar belakang tersebut di atas, maka dapat dirumuskan permasalahan sebagai berikut :

1. Bagaimanakah ketentuan UndangUndang No. 11 Tahun 2008 juncto Undang-Undang No. 19 Tahun 2016 tentang Informasi dan Transaksi Elektronik dalam perspektif sosiologi ?

2. Bagaimanakah dampak positif dan negatif dari perkembangan teknologi informasi di Indonesia ?

3. Bagaimanakah peran pemerintah dan masyarakat dalam penegakan UndangUndang No. 11 Tahun 2008 juncto Undang-Undang No. 19 Tahun 2016 tentang Informasi dan Transaksi Elektronik di Indonesia ?

\section{Kajian Teoritis}

Teori yang dipakai sebagai pisau analisis dalam penelitian ini adalah konsep "Hukum Sebagai Sarana Pembaharuan Masyarakat", yang diungkapkan oleh Mochtar Kusumaatmadja. Suatu konsepsi yang mempunyai kemiripan dengan konsep "law as as tool of social engineering" yang di Negara Barat pertama kali dipopulerkan oleh Aliran Pragmatic Legal Realism. ${ }^{7}$ Apabila konsepsi hukum sebagai sarana pembaharuan sebagai konsepsi ilmu hukum

${ }^{6}$ M. Khozim, Sistem Hukum : Perspektif Ilmu Sosial, (Bandung : Nusa Media, 2013), hlm. 124, terjemahan dari buku Lawrence M. Friedman, The Legal System : A Social Science Perspective, (New York : Russel Sage Foundation, 1975).

${ }^{7}$ Darji Darmodiharjo dan Shidarta, PokokPokok Filsafat Hukum, (Jakarta : Gramedia Pustaka Utama, 2006), hlm. 198. 
(sehingga sekaligus konsepsi pemikiran atau filsafat hukum, berbeda dari konsepsi politik hukum sebagai landasan kebijaksanaan) mirip atau sedikit banyak diilhami oleh teori "tool of social engineering". 8

Pengembangan konsepsional dari hukum sebagai sarana suatu pembaharuan masyarakat di Indonesia lebih luas jangkauannya serta ruang lingkupnya daripada di tempat kelahirannya sendiri di Amerika Serikat, karena beberapa hal yaitu:

1. Lebih menonjolnya perundangundangan dalam proses pembaharuan hukum di Indonesia, walaupun yurisprudensi juga memegang peranan, berlainan dengan keadaan di Amerika Serikat dimana Teori Roscoe Pound itu ditujukan terutama pada peranan pembaharuan pada keputusan-keputusan pengadilan, khususnya keputusan Supreme Court sebagai Mahkamah Tertinggi;

2. Sikap yang menunjukkan kepekaan terhadap kenyataan masyarakat yang menolak aplikasi "mechanistis" daripada konsepsi "law as a tool of social engineering". Aplikasi mekanistis demikian yang digambarkan dengan kata "tool" akan mengakibatkan hasil yang tidak banyak berbeda dari penerapan "legisme" yang dalam sejarah hukum Indonesia (Hindia Belanda) telah ditentang dengan keras. Dalam perkembangan di Indonesia maka konsepsi (teoritis) hukum sebagai sarana pembaharuan ini dipengaruhi pula oleh pendekatan-pendekatan filsafat budaya dari Northrop dan pendekatan "policy-oriented" dari Laswell dan McDougal; dan

3. Apabila dalam pengertian "hukum" termasuk pula hukum internasional, maka di Indonesia sebenarnya telah menjalankan asas "hukum sebagai sarana pembaharuan" jauh sebelum konsepsi dimaksud dirumuskan secara resmi sebagai landasan kebijaksanaan hukum.

${ }^{8}$ Roscoe Pound, An Introduction of the Philosophy of Law, (London : Yale University Press, 1930), hlm. 99.

\begin{abstract}
Perumusan resmi dimaksud sesungguhnya merupakan perumusan pengalaman masyarakat dan bangsa Indonesia berdasarkan sejarah. Perombakan hukum dalam bidang pertambangan (termasuk minyak dan gas bumi), tindakan-tindakan pada bidang hukum laut, nasionalisasi perusahaanperusahaan milik Belanda, dan tindakan hukum di bidang telekomunikasi sebagaimana dituangkan dalam UndangUndang No. 11 Tahun 2008 juncto Undang-Undang No. 19 Tahun 2016 tentang Informasi dan Transaksi Elektronik bertujuan mengadakan suatu perubahan-perubahan yang mendasar merupakan perwujudan dari aspirasi bangsa Indonesia yang tertuang dalam bentuk hukum dan perundang-undangan.
\end{abstract}

Dalam pengamatan sosial terutama bidang sosiologi terhadap hukum (sebagai obyeknya), hukum selalu dipandang tidak otonom. Hukum tidak bisa berdiri sendiri dengan ketentuan perundang-undangan semata. Eugen Ehrlich menyatakan $:^{9}$

"at the present as well as any other time, the centre or gravity of legal development lies not in legislation, nor in jurist science nor in judicial decision, but in society it self" (baik kini dan di masa kapanpun, pusat kegiatan dan perkembangan hukum bukanlah dalam perundang-undangan, bukan dalam ilmu hukum, juga bukan dalam putusan pengadilan, tetapi di dalam masyarakat sendiri).

Berdasarkan teori yang dikemukakan oleh Eugen Erlich tersebut, menunjukkan bahwa masyarakat sebagai pusat perkembangan hukum tidak lain sebagai cikal bakal untuk lahirnya sebuah undangundang. Oleh sebab itu termasuk segala perubahan sosial yang terjadi pada masyarakat merupakan instrumen yang dapat memberi pengaruh terhadap pusat kegiatan dan perkembangan hukum untuk masa-masa selanjutnya. Tentu berdasarkan perkembangan hukum yang dipengaruhi

${ }^{9}$ Curzon, Juriprudence, (USA : M \& E Handbook, 1979), hlm. 169. 
oleh masyarakat tersebut, maka dipandang perlu untuk menguraikan secara kongkret pengaruh perubahan sosial terhadap perkembangan dalam aliran pemikiran hukum.

Penggunaan istilah "cyber law" ataupun "cyberspacelaw" untuk sistem hukum yang hidup dalam medium cyberspace, maka sebenarnya hal ini bermakna juga hidup dalam medium cyberspace, maka sebenarnya hal ini berarti akan berbicara terhadap keberlakuan sistem hukum nasional terhadap segala aktivitas komunikasi dalam lingkup cyberspace itu sendiri.

Dalam konteks tersebut, dengan melihat hakikat yang mendasari lahirnnya cyberspace adalah konvergensi TELEMATIKA, ${ }^{10}$ maka untuk menghindari kesalahpahaman seharusnya kita mempopulerkan istilah Hukum Telematika ketimbang Hukum Cyberspace. Hal ini berarti bahwa domain-domain ketentuan hukum yang mungkin awalnya dipahami terpisah per sektor, (baik telekomunikasi, media dan informatika) akan menjadi semakin konvergen. Sehingga kita tidak menyatakan adanya kevakuman hukum, melainkan akan menarik suatu perbidangan hukum uang lebih khusus namun dengan tidak menafikkan keberlakuan bidangbidang hukum yang telah ada dalam sistem hukum yang berlaku.

Berdasarkan uraian di atas, maka perlu dipahami terlebih dahulu bahwa makna Hukum Telematika ialah hukum terhadap perkembangan konvergensi telematika yang berwujud dalam penyelenggaraan suatu sistem elektronik, baik yang terkoneksi melalui internet

\footnotetext{
${ }^{10}$ Asal-usul kata TELEMATIKA, berasal dari istilah Perancis "TELEMATIQUE" yang kemudian menjadi istilah umum di Eropa untuk memperlihatkan bertemunya sistem jaringan komunikasi dengan teknologi informasi. Sementara yang dimaksudkan dengan istilah teknologi informasi itu sendiri hanyalah merujuk kepada perkembangan teknologi perangkat-perangkat pengolah informasi.
}

(cyberspace) maupun yang tidak terkoneksi dengan internet.

Lingkup pengkajian adalah terfokus kepada setiap aspek-aspek hukum yang berkaitan dengan keberadaan sistem informasi dan sistem komunikasi itu sendiri, khususnya yang dilakukan dengan penyelenggaraan sistem elektronik, dengan tetap memperhatikan esensi dari: ${ }^{11}$

1. Keberadaan komponen-komponen dalam sistem tersebut, yakni mencakup: (i) perangkat keras, (ii) perangkat lunak, (iii) prosedur-preosedur, (iv) perangkat manusia, dan (v) informasi itu sendiri; dan

2. Keberadaan fungsi-fungsi teknologi di dalamnya yakni: (i) input, (ii) proses, (iii) output, (iv) penyimpanan dan (v) komunikasi.

Dalam praktiknya kedua variabel tersebut, dalam cyberspace dikenal sebagai empat komponen, yakni : ${ }^{12}$

1. Content, yakni keberadaan isi ataupun substansi dari data dan/atau informasi itu sendiri yang merupakan input dan output dari penyelenggaraan sistem informasi yang disampaikan kepada publik, mencakup semua bentuk data/informasi baik yang tersimpan dalam bentuk cetak maupun elektronik, ataupun yang disimpan sebagai basis data (databases) maupun yang dikomunikasikan sebagai bentuk pesan (data messages);

2. Computing, yakni keberadaan sistem pengelola informasi yang berbasiskan sistem komputer (computer based information system) yang merupakan jaringan sistem informasi (computer network) organisasional yang efisien, efektif dan juga legal. Dalam hal ini, suatu sistem informasi merupakan bentuk penerapan perkembangan teknologi informasi ke dalam suatu bentuk organisasional/organisasi perusahaan (bisnis);

${ }^{11}$ Edmon Makarim, Kompilasi Hukum Telematika, (Jakarta : RajaGrafindo Persada, 2004), hlm. 8.

${ }^{12}$ Ibid., hlm. 9. 
3. Communication, yakni keberadaan sistem komunikasi yang juga merupakan perwujudan dari sistem keterhubungan (interconnection) dan sistem pengoperasian global (interoperational) antar sistem informasi/jaringan komputer (computer network) ataupun penyelenggaraan jasa dan/atau jaringan telekomunikasi;

4. Community, yakni keberadaan masyarakat berikut sistem kemasyarakatannya yang merupakan pelaku intelektual (brainware), baik dalam kedudukannya sebagai pelaku usaha, profesional penunjang ataupun sebagai pengguna dalam sistem tersebut.

\section{B. Pembahasan}

\section{Ketentuan UU ITE Dalam Perspektif Sosiologi}

Secara sosiologis, perubahan UU ITE dilakukan karena adanya kehendak untuk memenuhi kebutuhan hukum masyarakat, termasuk di dalamnya hukum yang mencerminkan nilai-nilai budaya dari suatu bangsa (latency). Dimana banyaknya peristiwa yang memperlihatkan bahwa masyarakat menuntut cara yang berbeda dalam pengaturan intersepsi dan ancaman pencemaran nama baik yang dianggap terlalu berat sehingga sanksi hingga perlakuan terhadap pelanggarnya dianggap lebih berat dari perbuatan yang dilakukan.

Kondisi internal masyarakat Indonesia yang berkembang cepat seiring perkembangan yang terjadi serta adanya tuntutan akan kepastian hukum juga keadilan yang begitu kuat, menyebabkan rumusan pengaturan tentang pengaturan intersepsi ataupun penyadapan dengan menggunakan peraturan pemerintah telah dibatalkan padahal di satu sisi secara substansi pengaturan tersebut dibutuhkan sehingga perlunya pengaturan tentang intersepsi ataupun penyadapan yang lebih komprehensif. Pengaturan ini akan menjadi dasar dibutuhkannya pengaturan tentang intersepsi ataupun penyadapan dalam bentuk undang-undang.

Begitupun mengenai perubahan ancaman pidana dalam perbuatan pencemaran nama baik dalam UU ITE, adalah upaya negara dalam merespons aspirasi dan perubahan nilai yang ada dalam masyarakat. Tindakan ini menjadi landasan sehingga negara dapat lebih sensitif dan responsif atas kondisi yang terjadi, tanpa mengubah tujuan pengaturan UU ITE itu sendiri. Pendekatan tersebut diharapkan mampu menimbulkan ketahanan sosial yang lebih baik dalam melakukan penataan masyarakat dan mengarah pada tujuan negara yang adil serta sejahtera. ${ }^{13}$

Teknologi informasi dan komunikasi merupakan peralatan sosial yang penuh daya, yang bisa membantu ataupun mengganggu masyarakat dalam berbagai cara. Semua tergantung kepada cara penggunaannya, perkembangan dunia cyber ataupun dunia teknologi informasi dan juga komunikasi telah menyebabkan perubahan sosial, ekonomi, dan budaya secara signifikan berlangsung cepat, perubahan peradaban manusia secara global, dan menjadikan dunia ini menjadi tanpa batas, tidak terbatas oleh garis teritorial suatu negara. ${ }^{14}$

Perkembangan teknologi telah memberikan ruang serta peluang bagi penyebaran pornografi, sebut saja pemakaian komputer untuk menggandakan file-file bermuatan pornografi ke dalam video compact disc

${ }^{13}$ Laporan Penyelarasan Akhir Naskah Akademik Rancangan Undang-Undang tentang Perubahan Atas Undang-Undang Nomor 11 Tahun 2008 tentang Informasi dan Transaksi Elektronik, (Jakarta : BPHN, 2015), hlm. 97-98.

${ }^{14}$ O.C. Kaligis, Penerapan Undang-Undang Nomor 11 Tahun 2008 tentang Informasi dan Transaksi Elektronik Dalam Praktiknya, Cetakan Pertama, (Jakarta : Yarsif Watampone, 2012), hlm. 2. 
(VCD), kemudian dijual atau disewakan kepada orang yang berminat.

Menurut Dimitri Mahayana internet merupakan knowledge big bang (ledakan besar pengetahuan) yang ditandai dengan komunikasi elektromagnetoopis via satelit maupun kabel, didukung oleh eksistensi jaringan telefoni yang sudah ada dan segera didukung oleh ratusan satelit yang sedang dan akan diluncurkan. ${ }^{15}$

Secara etimologi, pornografi berasal dari dua suku kata, yaitu pornos dan grafi. Pornos, artinya suatu perbuatan yang asusila (dalam hal yang berhubungan dengan seksual), atau perbuatan yang bersifat tidak senonoh atau cabul. Grafi ialah gambar atau tulisan, yang dalam arti luas yang isi atau artinya menunjukkan atau menggambarkan sesuatu yang bersifat asusila ataupun menyerang rasa kesusilaan di masyarakat.

Pornografi bersifat relatif, artinya tergantung pada ruang, waktu, tempat juga orangnya serta kebudayaan suatu bangsa. Bahkan dalam lingkungan suatu bangsa sendiri, terjadi variasi pengertian pornografi itu, misalnya antara suku Aceh dan Bali, Minahasa dan Bugis terjadi perbedaan yang mencolok sekali. Pornografi tradisional biasanya dilakukan melalui media lama seperti buku, majalah, film dan video tape. Kehadiran internet dan cyberspace memberi warna tersendiri dalam persoalan pornografi.

Jaringan komunikasi global interaktif melalui fasilitas internet relay chat bisa digunakan untuk menyebarluaskan informasi tentang cerita ataupun gambar pornografi (baik untuk sisi gelap maupun sisi terang dari pornografi) ataupun disebut juga

${ }^{15}$ Dimitri Mahayana, Menjemput Masa Depan, Futuristik dan Rekayasa Masyarakat Menuju Era Global, (Bandung : Rosda, 2000), hlm. 21. cybersex. Ada dua macam dari cybersex dalam ruang chatting, yaitu Computer mediated interactive masturbation in real time dan Computer mediated telling of interactive sexual stories (in real time) with the intent of arousal. ${ }^{16}$

Sedangkan definisi pornografi menurut Undang-Undang No. 44 Tahun 2008 tentang Pornografi, yaitu gambar, sketsa, ilustrasi, foto, tulisan, suara, bunyi, gambar bergerak, animasi, kartun, percakapan, gerak tubuh, atau bentuk pesan lainnya melalui berbagai bentuk media komunikasi dan/atau pertunjukan di muka umum, yang memuat pencabulan atau eksploitasi seksual yang melanggar norma kesusilaan dalam masyarakat. ${ }^{17}$

Selanjutnya dinyatakan bahwa pengaturan pornografi berasaskan Ketuhanan Yang Maha Esa, penghormatan terhadap harkat dan martabat kemanusiaan, kebhinnekaan, kepastian hukum, nondiskriminasi, dan juga perlindungan terhadap warga negara. Berdasarkan pengertian pornografi yang terdapat dalam undang-undang tersebut dinyatakan pornografi secara luas, dalam arti yang dipublikasikan melalui berbagai bentuk media komunikasi. Namun, secara khusus masalah pornografi melalui dunia maya terdapat dalam lex specialis-nya, yaitu Undang-Undang No. 11 Tahun 2008 tentang Informasi dan Transaksi Elektronik. ${ }^{18}$

${ }^{16}$ Robin B. Hamman, "Cyberorgasm, Cybersex Amongst Multiple-Selves and Cyborgs in the Narrow-Bandwidth Space of America Online Chat Rooms", tersedia di http://www.cybersoc.com/Cyberorgasm.html., diakses tanggal 10 Mei 2016.

${ }^{17}$ Indonesia, Undang-Undang tentang Pornografi, UU Nomor 44 Tahun 2008, LN No. 181 Tahun 2008, TLN No. 4928, Pasal 1 angka 1.

${ }^{18}$ Ronny Waisan, "Aturan Tindak Pidana dalam UU Pornografi dan UU ITE tentang Informasi Elektronik Bermuatan Pornografi", tersedia di : http://ronny-hukum.blogspot.com/2009/04/tinjauanaturan-tindak-pidana-dalam-uи_01.html., diakses tanggal 13 Mei 2016. 
American Demographic Magazine yang menghitung jumlah situs porno dan jumlah halaman situs porno. Pada tahun 1997 terdapat 22.100 situs porno. Pada tahun 2000 meningkat menjadi 280.000 dan pada tahun 2003 meningkat hampir empat kali lipatnya, yaitu menjadi 1,3 juta situs porno. Sedangkan, halaman situs porno di dunia pada tahun 1998 terdapat 14 juta dan meningkat tajam pada tahun 2003, yaitu menjadi 260 juta. Pada tahun 2008, data terakhir halaman situs porno di dunia telah mencapai 420 juta. $^{19}$

Kenyataan ini tidak terelakkan. Sebagaimana dinyatakan oleh Dr. Robert Weiss dari Sexual Recovery Institute di Washington Times tahun 2000. Weiss menyatakan bahwa seks adalah topik nomor 1 yang dicari di internet. Studi lain yang dilakukan oleh MSNBC/Standford /Duquesne menyatakan bahwa $60 \%$ kunjungan internet adalah menuju ke situs sex (porno). Data ini disempurnakan oleh publikasi dari The Kaiser Family Foundation yang menyebutkan bahwa $70 \%$ kunjungan pengguna internet belasan tahun yaitu menuju ke situs pornografi. Penelitian lain yang dikeluarkan oleh TopTenReviews.Com menyatakan bahwa sebenarnya dominasi pengunjung internet di Amerika justru orang berumur $35-44$ tahun $(26 \%){ }^{20}$

Amerika merupakan Negara penyumbang terbesar $89 \%$ situs pornografi di dunia. Diikuti oleh Jerman, Inggris, Australia, Jepang dan Belanda menyusul di belakangnya. Meskipun Amerika penyumbang situs porno terbesar di dunia, ternyata hanya menduduki urutan keempat dalam jumlah pendapatan (revenue) dari industri pornografi di dunia. Pemenangnya justru China yang diikuti oleh Korea Selatan dan Jepang. Total pendapatan pertahun industri pornografi di dunia adalah sekitar 97 miliar USD, ini setara dengan total pendapatan perusahaan besar di Amerika yaitu: Microsoft, Google, Amazon, eBay,

\footnotetext{
${ }^{19}$ Tersedia di

http://www.TopTenReviews.Com, diakses tanggal 12 Mei 2016.

${ }^{20}$ Ibid.
}

Yahoo!, Apple, Netflix and EarthLink. Ini menunjukkan betapa dahsyatnya industri pornografi di dunia. ${ }^{21}$

Berkaitan ini, salah satu tulisan di CNET tahun 1999 menyebutkan bahwa: pornografi online adalah produk $e$ commerce yang secara konsisten menduduki peringkat pertama dalam bisnis di internet. Dari berbagai data tentang pornografi internet di atas, yang cukup mencengangkan bahwa ternyata penikmat dan juga penerima ekses negatif dari industri pornografi di internet bukan negara-negara produsen, tetapi justru negara-negara kecil dan berkembang sebagai konsumen. Dapat dilihat dari trend request pencarian dengan tiga kata kunci, yaitu $x x x$, porn dan sex, semuanya dikuasai oleh negara kecil atau berkembang seperti Pakistan, Afrika Selatan, India, Bolivia, Turki, dan juga Indonesia.

Menurut Dr. Mary Anne Layden seorang peneliti dari University of Pennsylvania, ${ }^{22}$ cyberporn membawa dampak yang tidak baik, yaitu :, Pertama, meningkatnya kriminalitas. Ia mengatakan, "Saya telah memberikan pendampingan terhadap pelaku dan juga korban kekerasan seksual selama 13 tahun. Dan saya belum pernah menangani 1 kasus pun yang tidak diakibatkan oleh Pornografi. Pornografi memicu agresivitas dan pada akhirnya memicu seseorang untuk melakukan perbuatan kriminal."

Kedua, risiko terhadap psikologis dan pendidikan. Menurut VB Cline, seorang riserter masalah psikososial dan pornografi, mengungkapkan ada 4 tahapan perkembangan kecanduan seksual pada konsumer pornografi :

a. Adiksi atau ketagihan;

${ }^{21}$ Romi Satria Wahono, 2008, "Tahukan Anda Beberapa Kenyataan ini?", tersedia di : http://agungcyber.blogspot.com/2008/04/indonesiarangking-7-kupas-tuntas.html., diakses tanggal 12 Mei 2016.

${ }^{22}$ Ibid 
b. Eskalasi, yaitu : peningkatan kualitas ketagihan menjadi perilaku yang semakin menyimpang;

c. Desentisisasi, yaitu : kian menipisnya sensitivitas; dan

d. Acting Out, yaitu : pecandu pornografi mulai mempraktikkan.

Ketiga, risiko kesehatan. Menurut

Divisi Kesehatan ASA Indonesia Dewi Inong Irara, spesialis penyakit kulit dan kelamin, memaparkan risiko kesehatan yang diakibatkan oleh Penyakit Menular Seks (PMS) akibat pornografi adalah infeksi alat kelamin, komplikasi, penyakit alat kelamin dalam kronis, kanker kelamin, menular bayi dalam kandungan, dan HIV/ AIDS. Keempat, risiko kultural (pergeseran nilainilai). Saat ini sudah terlihat jelas akibat industri pornografi, banyak nilai-nilai budaya pada masyarakat tidak dihiraukan lagi, seperti hidupnya dunia malam yang identik dengan tempat-tempat pelacuran serta meningkatnya pelaku pornografi.

Secara umum Teori Rekayasa Sosial yang dikemukakan oleh Roscou Pound, dapat diharapkan sebagai output dari penerapan suatu peraturan perundangundangan, antara lain hukum diharapkan mampu mengubah masyarakat, karena hukum sebagai sarana perubahan masyarakat. Maksudnya pada zaman dahulu masyarakat belum memahami tentang informasi dan transaksi elektronik kemudian dengan perkembangan ilmu pengetahuan dan teknologi, sosial, ekonomi dan budaya yang sangat cepat. Hal tersebut menyebabkan pergeseran peradaban manusia dari era manual ke era otomatis. Sebagaimana dapat dicontohkan dahulu masyarakat apabila melakukan transaksi jual beli dengan bukti sebuah kuitansi, namun sekarang ini transaksi jual beli cukup melalui e-banking, kartu kredit dan lain-lain.

Selanjutnya dijelaskan bahwa UU ITE merupakan sebuah terobosan atau langkah maju untuk melindungi pengguna teknologi informasi agar teknologi dapat dimanfaatkan oleh masyarakat dan stakeholder lainnya. Selain itu hukum memiliki berbagai fungsi, yaitu sebagai sarana pengendalian masyarakat (a tool of social maintenance), sarana untuk menyelesaikan konflik (a tool of dispute settlement), sarana pembaharuan/alat merekayasa masyarakat.

Untuk melihat faktor-faktor yang mempengaruhi penegakan UU ITE, bisa dipakai Teori Lawrence M. Friedman, berkaitan dengan sistem hukum yang terdiri dari 3 (tiga) elemen, yaitu struktur hukum (legal structure), substansi hukum (legal substance) dan budaya hukum (legal culture) ${ }^{23}$

Kaitannya dengan penerapan UU ITE, yaitu: (i) Struktur Hukum (legal structure) masih minimnya kemampuan para aparat penegak hukum khususnya penyidik maupun penuntut umum dalam penguasaan teknologi yang berdampak pada keberhasilan dalam pengungkapan tindak pidana terkait; (ii) Substansi Hukum (legal substance) substansi UU ITE sudah cukup memadai jangkauan pengaturannya cukup luas demikian pula dengan pengaturan sanksi pidananya, namun karena belum disosialisasikan dengan baik sehingga jangkauan penegakan undang-undang ini masih minim; (iii) Budaya Hukum (legal culture). Dari cara bekerjanya struktur hukum dan substansi hukum di atas menimbulkan degradasi budaya hukum pada masyarakat, hal tersebut ditandai dengan belum efektifnya penerapan undang-undang dikarenakan undang-undang ini belum tersosialisasikan dengan baik di masyarakat sehingga kemudian berakibat pada efektivitas penegakan hukum undangundang tersebut.

Dalam kenyataannya, perjalanan implementasi dari UU ITE tersebut

\footnotetext{
${ }^{23}$ Inosentius Samsul, Perlindungan Konsumen : Kemungkinan Penerapan Tanggung Jawab Mutlak, (Jakarta : Program Pascasarjana Fakultas Hukum Universitas Indonesia, 2004), hlm. 22.
} 
mengalami persoalan-persoalan sebagai berikut $:^{24}$

Pertama, terhadap undang-undang ini sudah diajukan beberapa kali uji materiil di Mahkamah Konstitusi dengan Putusan Mahkamah Konstitusi No. 50/PUU-VI/2008, No. 2/PUU-VII/2009, No. 5/PUUVIII/2010, dan No. 20/PUU-XIV/2016.

Berdasarkan Putusan Mahkamah Konstitusi No. 50/PUU-VI/2008 dan No. 2/PUU-VII/2009, tindak pidana penghinaan dan pencemaran nama baik dalam bidang informasi dan transaksi ektronik bukan semata-mata sebagai tindak pidana umum, melainkan sebagai delik aduan. Penegasan mengenai delik aduan dimaksudkan agar selaras dengan asas kepastian hukum dan rasa keadilan masyarakat.

Berdasarkan Putusan Mahkamah Konstitusi No. 5/PUU-VIII/2010, Mahkamah Konstitusi berpendapat bahwa kegiatan dan kewenangan penyadapan merupakan hal yang sangat sensitif karena di satu sisi merupakan suatu pembatasan hak asasi manusia, akan tetapi di sisi lain mempunyai aspek kepentingan hukum. Oleh sebab itu, suatu pengaturan (regulation) tentang legalitas penyadapan harus dibentuk dan juga diformulasikan secara tepat dan sesuai dengan UUD NRI Tahun 1945. Di samping itu, Mahkamah berpendapat bahwa karena penyadapan merupakan pelanggaran atas hak asasi manusia sebagaimana ditegaskan dalam Pasal 28J ayat (2) UUD NRI Tahun 1945, sangat wajar dan sudah sepatutnya bila negara ingin menyimpangi hak privasi warga negara tersebut, negara haruslah menyimpanginya dalam bentuk undangundang dan bukan dalam bentuk peraturan pemerintah.

Selain itu, berdasarkan Putusan Mahkamah Konstitusi No. 20/PUUXIV/2016, Mahkamah Konstitusi

\footnotetext{
${ }^{24}$ Indonesia, Undang-Undang tentang Perubahan Atas UU Nomor 11 Tahun 2008 tentang Informasi dan Transaksi Elektronik, UU Nomor 19 Tahun 2016, LN No. 251 Tahun 2016, TLN No. 5952, Penjelasan Umum.
}

berpendapat bahwa untuk mencegah terjadinya perbedaan penafsiran terhadap Pasal 5 ayat (1) dan ayat (2) UU ITE, Mahkamah menegaskan bahwa setiap intersepsi harus dilakukan secara sah, terlebih lagi dalam rangka penegakan hukum. Oleh sebab itu, Mahkamah dalam amar putusannya menambahkan kata atau frasa "khususnya" terhadap frasa "informasi elektronik dan/atau dokumen elektronik". Agar tidak terjadi sebuah penafsiran bahwa putusan tersebut akan mempersempit makna ataupun arti yang terdapat pada Pasal 5 ayat (1) dan ayat (2) UU ITE, untuk memberikan suatu kepastian hukum keberadaan informasi elektronik dan/atau dokumen elektronik sebagai alat bukti perlu dipertegas kembali dalam Penjelasan Pasal 5 UU ITE.

Kedua, ketentuan mengenai penggeledahan, penyitaan, penangkapan, dan penahanan yang diatur dalam UU ITE menimbulkan permasalahan bagi penyidik karena tindak pidana dalam bidang teknologi informasi dan transaksi elektronik begitu cepat dan pelaku bisa dengan mudah mengaburkan perbuatan atau alat bukti kejahatan.

Ketiga, karakteristik virtualitas ruang siber memungkinkan konten ilegal seperti informasi dan/atau dokumen elektronik yang mempunyai muatan yang melanggar kesusilaan, perjudian, penghinaan ataupun pencemaran nama baik, pemerasan dan/atau pengancaman, penyebaran berita bohong dan menyesatkan sehingga mengakibatkan kerugian konsumen dalam transaksi elektronik, serta perbuatan menyebarkan kebencian atau permusuhan berdasarkan suku, agama, ras, dan golongan, dan juga pengiriman ancaman kekerasan ataupun menakut-nakuti yang ditujukan secara pribadi bisa diakses, didistribusikan, ditransmisikan, disalin, disimpan untuk didiseminasi kembali dari mana saja dan juga kapan saja. Dalam rangka melindungi kepentingan umum dari segala jenis gangguan sebagai akibat penyalahgunaan informasi dan transaksi 
elektronik, diperlukan penegasan peran pemerintah dalam mencegah penyebarluasan konten ilegal dengan melakukan suatu tindakan pemutusan akses terhadap informasi elektronik dan/atau dokumen elektronik yang mempunyai muatan yang melanggar hukum agar tidak bisa diakses dari yurisdiksi Indonesia serta dibutuhkan kewenangan bagi penyidik untuk meminta informasi yang terdapat dalam penyelenggara sistem elektronik untuk kepentingan penegakan hukum tindak pidana di bidang teknologi informasi dan transaksi elektronik.

$\begin{array}{ccc}\text { Keempat, } & \text { penggunaan setiap } \\ \text { informasi melalui media atau sistem }\end{array}$ elektronik yang menyangkut data pribadi seseorang harus dilakukan atas persetujuan orang yang bersangkutan. Untuk itu, dibutuhkan jaminan pemenuhan perlindungan diri pribadi dengan mewajibkan setiap penyelenggara sistem elektronik untuk menghapus informasi elektronik dan/atau dokumen elektronik yang tidak relevan yang berada di bawah kendalinya atas permintaan orang yang bersangkutan berdasarkan penetapan pengadilan.

\section{Dampak Positif dan Negatif Keberadaan UU ITE}

Menurut Edmon Makarim, bahwa UU ITE ini memang memiliki dampak positif juga negatifnya. Contoh dampak positif yang mungkin muncul di masa dating ialah sebagai berikut $:^{25}$

a. Semua kegiatan pengajuan harga, kontak kerja sama, penagihan berbasis elektronik dilindungi hukum. Semua kiriman e-mail ke klien yang terdokumentasi bisa menjadi bahan pertimbangan hukum, bila suatu waktu terjadi masalah dalam proses kerja sama. Untuk orang yang kerjanya di ranah maya, tentu ini mempunyai nilai positif;

${ }^{25}$ Edmon Makarim, Dosen FH Universitas Indonesia (Penulis Buku Kompilasi Hukum Telematika), Wawancara, pada hari Selasa, 3 Mei 2016 di FH Universitas Indonesia Depok. b. Jika akan melakukan transaksi perbankan (misalnya melalui Klik BCA) dan dirugikan karena (misalnya) ketekan tombol submit 2 kali, dan ini tidak diantisipasi oleh pengelola transaksi, maka orang tersebut berhak secara hukum menuntut pengelola transaksi tersebut. Tuntutan ini dapat bisa berlaku untuk mereka yang menjadi merchant egold, PayPal, dan sebagainya;

c. Bila ada perusahaan yang mendaftarkan nama domain dengan maksud menjelekkan produk /merek /nama tertentu, perusahaan tersebut dapat dituntut untuk membatalkan nama domain;

d. Semua yang tertulis dalam sebuah blog menjadi resmi hak cipta penulisnya dan dilindungi hak kekayaan intelektualnya. Untuk itu berhati-hatilah menulis dalam blog, sebab tulisan negatif yang merugikan pihak lain, juga ikut resmi menjadi hak cipta penulisnya, dan itu bisa dituntut oleh pihak yang dirugikan;

e. Bila ada yang melakukan transaksi kartu kredit tanpa sepengetahuan pemilik kartu (carding), secara jelas bisa dituntut melalui hukum;

f. Hati-hati bagi yang sering nge-hack situs untuk mendapatkan database situs tersebut. Apalagi dengan tujuan menggunakannya untuk transaksi illegal, misal: menjual alamat e-mail tanpa sepengetahuan pemilik e-mail. Hal ini juga berlaku untuk para pemilik situs yang harus menjamin kerahasiaan anggotanya, dan tidak menjual database tersebut ke pihak lain. Ini juga termasuk kasus jual-menjual database pengguna telepon genggam ke bank untuk penawaran kartu kredit;

g. Situs-situs phising secara hukum dilarang;

h. Untuk pemilik blog atau forum bisa dengan lebih leluasa menghapus semua komentar yang berhubungan dengan makian, kata-kata kotor, menyinggung suku, agama, ras dan antargolongan (SARA), menjelekkan orang lain 
(termasuk nama pemilik blog), dan itu dilindungi hukum.

Sedangkan dampak negatif yang mungkin muncul di masa mendatang ialah sebagai berikut $:^{26}$

a. Isi sebuah situs dilarang ada muatan yang melanggar asas kesusilaan. Kesusilaan bersifat normatif. Mungkin situs yang menampilkan foto porno yang vulgar bisa jelas dianggap melanggar kesusilaan. Akan tetapi, apakah situs-situs edukasi AIDS dan alat-alat kesehatan yang juga ditujukan untuk orang dewasa dilarang ? Lalu, apakah forum-forum komunitas lesbian, gay, biseksual dan transgender (LGBT) atau yang (hampir) tidak ada pornonya juga dianggap melanggar kesusilaan? Lalu, apakah foto seorang masyarakat Papua bugil yang ditampilkan dalam sebuah blog juga dianggap melanggar kesusilaan?

b. Kekhawatiran para penulis blog dalam mengungkapkan pendapat. Karena UU ITE ini, bisa jadi para blogger semakin berhati-hati agar tidak menyinggung orang lain, menjelekkan produk atau merek tertentu, membuat tautan referensi atau membahas situs-situs yang dianggap illegal oleh undang-undang, dan lain-lain. Kalau ketakutan menjadi semakin berlebihan, bukanlah malah semakin mengekang kebebasan berpendapat?

c. Seperti biasa, yang lebih mengkhawatirkan bukan undangundangnya, tetapi lebih kepada pelaksanaannya. Semoga UU ITE ini tidak menjadi alat bagi aparat untuk melakukan investigasi berlebihan sehingga menyentuh ranah pribadi.
3. Peran Pemerintah dan Peran Masyarakat Dalam Pemanfaatan Teknologi Informasi dan Transaksi Elektronik

\section{a. Peran Pemerintah}

Pengertian peran pemerintah dalam Pasal 40 UU ITE ialah (i) pemerintah memfasilitasi pemanfaatan teknologi informasi dan juga transaksi elektronik; (ii) melindungi kepentingan umum dari segala jenis gangguan sebagai akibat penyalahgunaan informasi elektronik dan transaksi elektronik yang mengganggu ketertiban umum, sesuai dengan peraturan perundang-undangan; Pemerintah menetapkan instansi atau institusi yang mempunyai data elektronik strategis yang wajib dilindungi; (iv) Instansi atau institusi sebagaimana dimaksud pada butir (iii) harus membuat dokumen elektronik dan rekam cadang elektroniknya setelah menghubungkannya ke pusat data tertentu untuk kepentingan pengamanan data; (v) Instansi atau institusi lain selain diatur pada butir (iv) membuat dokumen elektronik dari rekam cadang elektroniknya sesuai dengan keperluan dengan perlindungan data yang dimilikinya.

\section{b. Peran Masyarakat}

Peran masyarakat diatur pada Pasal 41 UU ITE, yang dimaksud peran masyarakat dalam hal ini adalah : (i) masyarakat bisa berperan meningkatkan pemanfaatan teknologi informasi melalui penggunaan dan penyelenggaraan sistem elektronik dan transaksi elektronik sesuai dengan undang-undang ini (ii) Peran masyarakat sebagaimana dimaksud pada butir (i) bisa diselenggarakan melalui lembaga yang dibentuk oleh masyarakat yaitu lembaga yang bergerak di bidang tehnologi informasi dan transaksi elektronik 
(iii) Lembaga sebagaimana dimaksud pada butir (ii) dapat memiliki fungsi konsultasi dan mediasi.

Masyarakat mempunyai peran yang cukup penting dalam UU ITE. Sejumlah pasal mengatur tentang peran masyarakat. Pasal-pasal tersebut antara lain Pasal 23 ayat (1) dan (3), Pasal 24 ayat (1), Pasal 38 ayat (2), dan Pasal 41. Dari rumusan pasal-pasal itu terlihat bahwa urusan menegakkan hukum internet oleh negara tidak akan berhasil tanpa sokongan masyarakat, baik masyarakat secara umum maupun masyarakat pengguna internet.

Mengacu pada pendapat Antonio Segura-Serrano yang mengklasifikasikan 3 kelompok yang mempunyai pandangan berbeda mengenai hukum internet, masyarakat memiliki peran yang tidak kecil dalam menjaga kenyamanan ataupun bekerjanya suatu kondisivitas di ruang maya. Masyarakat memiliki peran yang sentral karena tujuan hukum internet sebenarnya adalah untuk mengatur masyarakat, manusia yang saling berinteraksi di ruang-maya. Masyarakat, berdasarkan pendapat Antonio Segura-Serrano, bahkan dimungkinkan untuk membentuk hukum internetnya sendiri. ${ }^{27}$

Pada kenyataannya, suatu negara berdaulat selalu berupaya memperluas dan menegakkan kedaulatannya hingga batas yang paling jauh. UU ITE ialah bukti nyata hasrat negara (Indonesia) untuk menegakkan kedaulatannya di ruang-maya. Padahal menurut Satjipto Rahardjo, selain hukum negara, ada kekuatan lain yang

${ }^{27}$ Antonio Segura-Serrano, "Internet Regulation and the Role of International Law", dalam A. von Bogdandy dan R. Wolfrum (ed.), Max Planck Yearbook of United Nations Law Volume 10 (Netherlands: Koninklijke Brill, 2006), hlm. 194. diam-diam bekerja di masyarakat. ${ }^{28}$ Berhadapan dengan kekuatankekuatan sosial di luar dirinya, hukum hanya akan menempati kedudukan yang bersifat tergantung pada permainan kekuatan-kekuatan tersebut. $^{29}$

Oleh sebab itu, harus ada relasi yang harmonis diantara masyarakat dan negara dalam menyusun dan menegakkan hukum pada ruang maya. Negara bisa saja menetapkan peraturan, menyusun sanksi, dan menentukan apa yang boleh dan tidak boleh dilakukan di ruang maya, namun semua itu tidak akan pernah efektif jika tidak didukung oleh peran serta dan dukungan masyarakat. Fungsi negara di ruang maya sejatinya hanya mengatur tanpa mengganggu "kehidupan" (dalam hal ini kehidupan di ruang maya) yang sudah berjalan. Negara seyogianya datang manakala terjadi sengketa di antara masyarakat pengguna internet, bukan malah menjadi biang terjadinya kekisruhan. Sebab, menegakkan hukum di masyarakat bukan berarti harus dengan mengintervensi masyarakat secara total, melainkan dengan membuat skema besar yang proses-proses kongkretnya diserahkan kepada masyarakat. ${ }^{30}$

Juga harus dipastikan bahwa apakah persoalan yang muncul di ruang maya mesti diselesaikan oleh dan melalui hukum ? Pengetahuan tentang ini, menurut Satjipto Rahardjo, bergantung pada konsep hukum yang kita miliki. Pembuatan hukum internet harus berorientasi kepada masyarakat, yakni pengguna internet itu sendiri, bukan semata-

${ }^{28}$ Satjipto Rahardjo, Penegakan Hukum Progresif, (Jakarta: Kompas, 2010), hlm. 204.

${ }^{29}$ Satjipto Rahardjo, Hukum dan Masyarakat, (Bandung : Angkasa, 1980), hlm. 20.

${ }^{30}$ Satjipto Rahardjo, Hukum Dalam Jagat Ketertiban, (Jakarta : UKI Press, 2006), hlm. 89. 
mata fokus pada peraturan yang diharapkan dapat mengatasi segala permasalahan di ruang maya. ${ }^{31}$

Satjipto Rahardjo juga menjelaskan bahwa sebelum menyusun hukum sebaiknya dimulai suatu penelitian mengenai sasaransasaran dari hukum tersebut. Menyusun hukum internet berarti mengetahui seluk-beluk dan segala hal ihwal tentang internet. Satjipto Rahardjo mengatakan : "Hukum memiliki kelebihan, tetapi juga kekurangan-kekurangannya sendiri. Bahkan apabila tidak didahului oleh studi yang cermat, alih-alih membawa kebaikan, hukum malah bisa menimbulkan "malapetaka". Dengan penelitian yang cermat tidak dijamin bahwa suatu undang-undang akan berhasil. Studi pendahuluan yang cermat itu hanya akan mengurangi risiko timbulnya efek negatif. ${ }^{32}$

Penyusunan instrumen hukum yang tidak diawali dengan penelitian pendahuluan, dengan demikian, terang tidak akan memberi hasil yang tepat benar dengan tujuan yang ingin dicapai. Internet memiliki sistem dan masyarakatnya sendiri. Pengguna jejaring sosial facebook, misalnya, mesti tunduk pada aturan yang telah ditetapkan facebook.

Apabila ada pengguna yang melanggar salah satu klausul yang dibuat oleh facebook, pengelola facebook dapat menjatuhkan sanksi yang dampaknya jauh lebih efektif ketimbang apa yang ditetapkan oleh negara melalui hukumnya. Sebagai contoh, bagi pengguna tertentu yang menyebarkan muatan pornografi, facebook akan segera bertindak dengan menghapus muatan tersebut dari lamannya. Facebook pun dapat membatalkan akun pengguna internet yang bersangkutan sehingga pengguna tidak bisa lagi beraktivitas

\footnotetext{
${ }^{31}$ Ibid., hlm. 86 .

${ }^{32}$ Ibid., hlm. 87.
}

di facebook dengan menggunakan akun pribadinya.

Permisalan semacam itu hanya untuk menjelaskan bahwa di internet pemegang otoritas sesungguhnya bukan negara, melainkan server atau pengelola situs-web yang bersangkutan. Dengan kata lain, pemegang kontrol internet tertinggi adalah masyarakat pengguna internet itu sendiri. Sehingga, dengan demikian, posisi masyarakat sesungguhnya begitu sentral dalam rangka mewujudkan nilai-nilai baik yang hendak dicapai dari suatu peraturan.

\section{Kesimpulan}

a. Ketentuan Undang-Undang No. 11 Tahun 2008 juncto Undang-Undang No. 19 Tahun 2016 tentang Informasi dan Transaksi Elektronik dalam perspektif sosiologi adalah karena adanya kehendak untuk memenuhi kebutuhan hukum masyarakat, termasuk di dalamnya hukum yang mencerminkan nilai-nilai kebudayaan dari suatu bangsa (latency). Dimana banyaknya peristiwa yang memperlihatkan bahwa masyarakat menuntut cara yang berbeda dalam pengaturan intersepsi dan ancaman pencemaran nama baik yang dianggap terlalu berat sehingga sanksi hingga perlakuan terhadap pelanggarnya dianggap lebih berat dari perbuatan yang dilakukan. Kondisi internal masyarakat Indonesia yang berkembang cepat seiring perkembangan yang terjadi serta adanya tuntutan akan kepastian hukum dan keadilan yang begitu kuat, menyebabkan rumusan pengaturan tentang pengaturan intersepsi atau penyadapan dengan menggunakan peraturan pemerintah telah dibatalkan padahal di satu sisi secara substansi pengaturan tersebut dibutuhkan sehingga perlunya pengaturan mengenai intersepsi atau penyadapan 
yang lebih komprehensif. Pengaturan ini akan menjadi dasar dibutuhkannya pengaturan tentang intersepsi ataupun penyadapan dalam bentuk undangundang. Begitupun mengenai perubahan ancaman pidana dalam perbuatan pencemaran nama baik dalam UU ITE, adalah upaya negara dalam merespons aspirasi dan perubahan nilai yang ada di masyarakat. Tindakan ini menjadi landasan sehingga negara dapat lebih sensitif dan responsif atas kondisi yang terjadi, tanpa mengubah tujuan pengaturan UU ITE itu sendiri. Pendekatan tersebut diharapkan dapat menimbulkan ketahanan sosial yang lebih baik dalam melakukan penataan masyarakat dan mengarah pada tujuan negara yang adil dan sejahtera;

b. Dampak positif dan negatif dari perkembangan teknologi informasi di Indonesia adalah:

1)Dampak positifnya, antara lain :

a) Semua kegiatan pengajuan harga, kontak kerja sama, penagihan berbasis elektronik dilindungi hukum. Semua kiriman e-mail keklien yang terdokumentasi dapat menjadi suatu bahan pertimbangan hukum, bila suatu waktu terjadi masalah dalam proses kerja sama. Untuk orang yang kerjanya di ranah maya, tentu ini memiliki nilai positif;

b) Jika akan melakukan transaksi perbankan (misalnya melalui Klik BCA) dan dirugikan karena (misalnya) ketekan tombol submit 2 kali, dan ini tidak diantisipasi oleh pengelola transaksi, maka orang tersebut berhak secara hukum menuntut pengelola transaksi tersebut. Tuntutan ini juga dapat berlaku untuk mereka.

c) yang menjadi merchant egold, PayPal, dan sebagainya;

d) Bila ada perusahaan yang mendaftarkan nama domain dengan maksud menjelekkan produk/merek/nama tertentu, perusahaan tersebut bisa dituntut untuk membatalkan nama domain

e) Bila ada yang melakukan transaksi kartu kredit tanpa sepengetahuan pemilik kartu (carding), secara jelas dapat dituntut melalui hukum;

f) Situs-situs phising secara hukum dilarang;

g) Untuk pemilik blog atau forum bisa dengan lebih leluasa menghapus semua komentar yang berhubungan dengan makian, kata-kata kotor, menyinggung suku, agama, ras dan antargolongan (SARA), menjelekkan orang lain (termasuk nama pemilik blog), dan itu dilindungi hukum.

2) Dampak negatifnya, antara lain :

a) Isi sebuah situs dilarang muatan yang melanggar kesusilaan. Kesusilaan bersifat normatif. Mungkin situs yang menampilkan foto-foto porno secara terbuka bisa jelas dianggap melanggar kesusilaan. Namun, apakah situs-situs edukasi AIDS dan alat-alat kesehatan yang juga ditujukan untuk orang dewasa dilarang ? Lalu, apakah forumforum komunitas lesbian, gay biseksual dan transgender (LGBT) atau yang (hampir) tidak ada pornonya juga dianggap sebagai melanggar kesusilaan? Lalu, apakah foto seorang masyarakat Papua bugil yang ditampilkan dalam sebuah blog juga dianggap melanggar kesusilaan?

b) Kekhawatiran para penulis blog dalam mengungkapkan pendapat. Karena UU ITE ini, bisa saja para blogger semakin berhati-hati agar tidak menyinggung orang lain, menjelekkan produk atau merek tertentu, membuat tautan referensi atau membahas situs- 
situs yang dianggap illegal oleh undang-undang, dan lain-lain. apabila ketakutan menjadi semakin berlebihan, bukanlah malah semakin mengekang kebebasan berpendapat?

c) Seperti biasa, yang lebih mengkhawatirkan bukan undangundangnya, tetapi lebih pada pelaksanaannya. Semoga UU ITE ini tidak menjadi alat bagi aparat untuk melakukan investigasi berlebihan sehingga menyentuh ranah pribadi.

d) Peran pemerintah dan masyarakat dalam penegakan Undang-Undang No. 11 Tahun 2008 juncto Undang-Undang No. 19 Tahun 2016 tentang Informasi dan Transaksi Elektronik di Indonesia adalah sebagai berikut :

1) Peran Pemerintah

a) Memfasilitasi pemanfaatan teknologi informasi dan transaksi elektronik;

b) Melindungi kepentingan umum dari segala jenis gangguan sebagai akibat penyalahgunaan informasi elektronik dan transaksi elektronik yang mengganggu ketertiban umum, sesuai dengan peraturan perundang-undangan;

c) Pemerintah menetapkan instansi atau institusi yang memiliki data elektronik strategis yang wajib dilindungi; d) Instansi atau institusi sebagaimana dimaksud pada butir c) harus membuat dokumen elektronik dan rekam cadang elektroniknya setelah menghubungkannya ke pusat data tertentu untuk kepentingan pengamanan data;

e) Instansi atau institusi lain selain diatur pada butir d) membuat dokumen elektronik dari rekam cadang elektroniknya sesuai dengan keperluan dengan perlindungan data yang dimilikinya

2) Peran Masyarakat

a) Masyarakat dapat berperan meningkatkan pemanfaatan teknologi informasi melalui penggunaan dan penyelenggaraan sistem elektronik dan transaksi elektronik sesuai dengan undang-undang ini;

b) Peran masyarakat sebagaimana dimaksud pada butir a) dapat diselenggarakan melalui lembaga yang dibentuk oleh masyarakat yaitu lembaga yang bergerak di bidang teknologi informasi dan transaksi elektronik;

c) Lembaga sebagaimana dimaksud pada butir b) dapat memiliki fungsi konsultasi dan mediasi.

\section{DAFTAR PUSTAKA}

\section{A. Buku}

Arief, Barda Nawawi. Tindak Pidana Mayantara : Perkembangan Kajian Cyber Crime di Indonesia. Jakarta : RajaGrafindo Persada, 2007.

Curzon. Juriprudence. USA : M \& E Handbook, 1979.

Darmodiharjo, Darji dan Shidarta. Pokok-Pokok Filsafat Hukum. Jakarta : Gramedia Pustaka Utama, 2006.

Kaligis, O.C. Penerapan Undang-Undang Nomor 11 Tahun 2008 tentang Informasi dan Transaksi Elektronik Dalam Prakteknya. Cetakan Pertama. Jakarta : Yarsif Watampone, 2012. 
Khozim, M. Sistem Hukum : Perspektif Ilmu Sosial. Bandung : Nusa Media, 2013. Terjemahan dari buku Lawrence M. Friedman. The Legal System : A Social Science Perspective. New York : Russel Sage Foundation, 1975.

Mahayana, Dimitri. Menjemput Masa Depan, Futuristik dan Rekayasa Masyarakat Menuju Era Global. Bandung : Rosda, 2000.

Makarim, Edmon. Kompilasi Hukum Telematika. Jakarta : RajaGrafindo Persada, 2004.

Pound, Roscoe. An Introduction of the Philosophy of Law. London : Yale University Press, 1930.

Rahardjo, Satjipto. Penegakan Hukum Progresif. Jakarta: Kompas, 2010. . Hukum dan Masyarakat. Bandung: Angkasa, 1980.

. Hukum Dalam Jagat Ketertiban. Jakarta : UKI Press, 2006.

Ramli, Ahmad M. Cyber Law dan HAKI Dalam Sistem Hukum Indonesia. Bandung : Refika Aditama, 2004.

Riswandi, Budi Agus. Hukum dan Internet di Indonesia. Yogyakarta : UII Press, 2003.

Samsul, Inosentius. Perlindungan Konsumen : Kemungkinan Penerapan Tanggung Jawab Mutlak. Jakarta : Program Pascasarjana Fakultas Hukum Universitas Indonesia, 2004.

Serrano, Antonio Segura-. "Internet Regulation and the Role of International Law". dalam A. von Bogdandy dan R. Wolfrum (ed.). Max Planck Yearbook of United Nations Law Volume 10. Netherlands: Koninklijke Brill, 2006.

Zein, Yahya Ahmad. Kontrak Elektronik dan Penyelesaian Sengketa Bisnis E-Commerce : Dalam Transaksi Nasional dan Internasional. Bandung : Mandar Maju, 2009.

\section{B. Peraturan Perundang-undangan}

Indonesia. Undang-Undang Dasar Negara Republik Indonesia Tahun 1945. Amandemen Keempat.

Undang-Undang tentang Informasi dan Transaksi Elektronik. UU Nomor 11 Tahun 2008. LN No. 58 Tahun 2008. TLN No. 4843.

Undang-Undang tentang Pornografi. UU Nomor 44 Tahun 2008. LN No. 181 Tahun 2008. TLN No. 4928.

- Undang-Undang tentang Perubahan Atas UU Nomor 11 Tahun 2008 tentang Informasi dan Transaksi Elektronik. UU Nomor 19 Tahun 2016. LN No. 251 Tahun 2016. TLN No. 5952.

Peraturan Pemerintah tentang Penyelenggaraan Sistem dan Transaksi Elektronik. PP Nomor 82 Tahun 2012. LN No. 189 Tahun 2012. TLN No. 5348.

\section{Lain-lain}

Black, Henry Campbell. Black's Law Dictionary. Sixth Edition. St. Paul, Minn. : West Publishing Co., 1991.

Blumen, Jonathan. "Is Pornography Bad ?", tersedia di : http://www.spectacle. org/is_pornography_bad.html. diakses tanggal 10 Mei 2016.

Departemen Pendidikan Nasional. Kamus Bahasa Indonesia. Jakarta : Pusat Bahasa, 2014.

Hamman, Robin B. "Cyberorgasm, Cybersex Amongst Multiple-Selves and Cyborgs in the Narrow-Bandwidth Space of America Online Chat Rooms". Tersedia di http://www.cybersoc.com/Cyberorgasm.html., diakses tanggal 10 Mei 2016.

Garner, Bryan A. Black's Law Dictionary. Abridged Ninth Edition. St. Paul Minnesota : West Publishing Co., 2010.

https://nasional.tempo.co/read/news/2013/09/06/063510985/tak-hanya-benhan-inikorban-uu-ite/4. diakses tanggal 9 Mei 2016. 
http://www.TopTenReviews.Com. diakses tanggal 12 Mei 2016.

Laporan Penyelarasan Akhir Naskah Akademik Rancangan Undang-Undang tentang Perubahan Atas Undang-Undang Nomor 11 Tahun 2008 tentang Informasi dan Transaksi Elektronik. Jakarta : BPHN, 2015.

Makarim, Edmon. Dosen FH Universitas Indonesia (Penulis Buku Kompilasi Hukum Telematika). Wawancara, pada hari Selasa, 3 Mei 2016 di FH Universitas Indonesia Depok.

Maulana, Insan Budi. "Informasi Komunikasi dan Teknologi : Perkembangan dan Perubahan Hukum". Materi Kuliah Hukum dan Teknologi Informasi pada Program Doktor Ilmu Hukum Program Pascasarjana Fakultas Hukum Universitas Sebelas Maret Surakarta, 20 Mei 2016.

Purwadarminta, W.J.S. Kamus Umum Bahasa Indonesia. Jakarta : Balai Pustaka, 1983.

Sanusi, M. Arsyad. Hukum dan Teknologi Informasi, Cet. 3, 2005. Baca juga Susilo Bambang Yudoyono "Sumbangan ICT dalam Membangun Good Govenrannce Amat Besar" dimuat dalam e-Indonesia, Vol. 1, Edisi Juni 2005.

Subekti, R. dan R. Tjitrosoedibio. Kamus Hukum. Jakarta : Pradnya Paramita, 1982.

Sudarsono. Kamus Hukum. Edisi Baru. Cetakan Kelima. Jakarta : Rineka Cipta, 2007.

Wahono, Romi Satria. 2008, “Tahukan Anda Beberapa Kenyataan ini?”, tersedia di : http://agungcyber.blogspot.com/2008/04/indonesia-rangking-7-kupastuntas.html., diakses tanggal 12 Mei 2016.

Waisan, Ronny. "Aturan Tindak Pidana dalam UU Pornografi dan UU ITE tentang Informasi Elektronik Bermuatan Pornografi". Tersedia di : http://ronnyhukum.blogspot.com/2009/04/tinjauan-aturan-tindak-pidana-dalamuu_01.html., Diakses tanggal 13 Mei 2016.

Wiwoho, Jamal. "Naskah Akademik Rancangan Undang-Undang tentang Informasi dan Transaksi Elektronik". Tersedia di http://jamalwiwoho.com/wpcontent/uploads/2010/10/NA-RUU-ITE.pdf, diakses tanggal 15 Agustus 2016. 